Chapman University

Chapman University Digital Commons

Sociology Faculty Articles and Research

Sociology

4-17-2019

\title{
Bad Habitus: Anthropology in the Age of the Multimodal
}

Stephanie Takaragawa

Chapman University, takaraga@chapman.edu

Trudi Lynn Smith

University of Victoria

Kate Hennessy

Simon Fraser University

Patricia Alvarez Astacio

Brandeis University

Jenny Chio

University of Southern California

See next page for additional authors

Follow this and additional works at: https://digitalcommons.chapman.edu/sociology_articles

Part of the Other Anthropology Commons, and the Social and Cultural Anthropology Commons

\section{Recommended Citation}

Takaragawa, S., Smith, T. L., Hennessy, K., Astacio, P. A., Chio, J., Nye, C., \& Shankar, S. (2019). Bad habitus: Anthropology in the age of the multimodal. American Anthropologist, 121(2), 517-524. https://doi.org/10.1111/aman.13265

This Article is brought to you for free and open access by the Sociology at Chapman University Digital Commons. It has been accepted for inclusion in Sociology Faculty Articles and Research by an authorized administrator of Chapman University Digital Commons. For more information, please contact laughtin@chapman.edu. 


\section{Bad Habitus: Anthropology in the Age of the Multimodal}

\section{Comments}

This is a pre-copy-editing, author-produced PDF of an article accepted for publication in American Anthropologist, volume 121, issue 2, in 2019 following peer review. The definitive publisher-authenticated version is available online at DOI: $10.1111 /$ aman.13265

\section{Copyright}

American Anthropological Association

\section{Authors}

Stephanie Takaragawa, Trudi Lynn Smith, Kate Hennessy, Patricia Alvarez Astacio, Jenny Chio, Coleman Nye, and Shalini Shankar 


\section{Bad Habitus: Anthropology in the Age of the Multimodal \\ Stephanie Takaragawa, Trudi Lynn Smith, Kate Hennessy, Patricia Alvarez Astacio, Jenny \\ Chio, Coleman Nye, Shalini Shankar \\ IN REVISION JANUARY 2019}

The recent reframing of the Visual Anthropology section in the journal American Anthropologist was motivated by a sense that new technologies have democratizing power, and that through multimodal forms we can address a shift toward engagement and collaboration in anthropological research (Collins, Durington and Gill 2017). Our purpose in this essay is to engage and expand the discussion raised by Samuel Collins, Matthew Durington, and Harjant Gill in their 2017 article Multimodal Anthropology: An Invitation, which has been widely cited and helped to inspire a range of new projects in anthropology that do not prioritize text. Although the idea of multimodal anthropology may challenge dominant paradigms of authorship, expertise, capacity, and language, we argue that there is nothing inherently liberatory about multimodal approaches in anthropology. Therefore, as our discipline(s) increasingly advocate for the multimodal in the service of anthropology, there is a need for deep engagement with the multimodal's position as an expression of technoscientific praxis, which is complicit in the reproduction of power hierarchies in the context of global capitalism, "capital accumulation" (Collins, Durington and Gill 2017:144) and other forms of oppression.

The kind of critical deep engagement we call for is not without precedent. Early critiques from filmmakers, like Trinh T. Minh-Ha, pointed to ethnographic film's complicity in reproducing a Western view of other cultures (Moore 1994). Trinh urged us not to drop our cameras, but to use them to reveal how a prevailing system of representation is naturalized and seen as the only truthful and correct way through the normalization of our ethnographic and cinematic methods and techniques. Such critiques inevitably called for a revision of our ethical engagements, a speaking nearby rather than speaking for (Chen and Trinh 1992, Trinh 1992, Ruby 1991). More recently, Harjant Gill asks the important question "how are our films and our scholarship continuously shaped by the various media-scapes within which they circulate, and how does institutional power condition what is knowable in the form of ethnographic accounts?" (2017:63 See also Gill 2016).

In a similar vein, we seek to interrogate the multimodal in our contemporary disciplinary context and praxis. The wide array and regular emergence of new technologies at our disposal to develop multimodal work demands us to consider broader questions relating to capitalism and technoscience that go beyond, but still include, considerations of film and the politics of representation. Moreover, questions of ethics will need to be redefined as new and more accessible or seemingly "democratic" technology will not solve certain ethical dilemmas but bring forth new ethical considerations to be recognized and addressed. Chen and Trinh's 25year old provocation resonates today in this regard:

If the tools are dealt with only as to further the production of anthropological knowledge, or to find a better solution for anthropology as a discipline, then what is achieved is either a refinement in the pseudo-science of appropriating Otherness or a 
mere stir within the same frame (Chen and Trinh 1992).

The OED (2018) defines multimodal as being "Characterized by several different modes of occurrence or activity; incorporating or utilizing several different methods or systems." The vanguard of contemporary multimodal work has been established at the University of Pennsylvania's Center for Experimental Ethnography and CAMRA under the stewardship of Deborah Thomas and John Jackson along with a cohort of graduate students who have held annual conferences dedicated to multimodal anthropology, produced blogs and exhibited multimodal work. Sarah Pink has explored multimodal scholarship as emerging from studies in phenomenology and of the senses (2009). Has the multimodal become equated with a more diverse methodological and technological tool kit? Within anthropology, how deeply are we looking at the systems that both produce the technologies being used and defining the work that can be done with them? Multimodal anthropology-characterized for example by the use of sound, photography, video, art, drawings, digitally produced graphic novels, performances, installation art, social media, cloud-based software, and mobile phones (and much more could and will be added to this list) — is a set of practices often deeply implicated in the digital and its invisible networks and resource-hungry requirements. If we are to take obligations within multimodal praxis seriously, we have to ask questions such as: how does the use of innovative technology elide and contribute to injustice and violences of extractive economies? What of the wave of suicides in Apple's iPhone factories in China (Condliffe 2010), the child and slave labour used in mining rare earth minerals (Kelly 2016), or the emergence of hyper-scale server farms (Vidal 2017)? How do algorithms operate within these extractive logics reproducing exclusions and experiences of violence faced by marginalized communities offline and online, such as the outsourcing of coders to the global south and the rampant PTSD diagnosis of content moderators in places like the Philippines (Noble 2017)? These are just some examples of exploitative and extractivist dynamics that feed our practices of using mobile phones and other technologies for representing knowledge.

Building on Sara Ahmed's (2007) concept of bad habits and Pierre Bourdieu's (1988) habitus, we are questioning how multimodal anthropologies may function to reproduce and reinforce a problem we call bad habitus. Here we suggest that multimodal anthropologies can just as easily reinforce existing power structures by making recourse to techno-fetishism or by dressing up neocolonial practices of extraction, inclusion, and appropriation in new language. Following Latour, who asks "what is kept of technoscience once all the trials of responsibility have been settled" (1987:174) —we wonder what do multimodal approaches to knowledge production privilege and what do they strategically deny? What does the multimodal preserve and promote and/or destroy in its world-making? Is multimodal anthropology a fetish object that disguises what is really going on? How do technologies work, how are they produced, by whom, and under what conditions (Harvey 2014:7)? We use this opportunity to theorize and conceptualize the potential of multimodal studies to not only make use of new tools and methods, but to investigate the reification of power hierarchies and privilege of technoscience that these tools and methods may enable. We want to analyze multimodal dynamics through a lens of global social justice by including investigations of labor, access, and mobility in the creation, dissemination, and maintenance of new technologies. 
The discussions leading up to this essay began amongst three members of the Ethnographic Terminalia Collective (Stephanie, Trudi, and Kate), who along with co-curators Craig Campbell and Fiona McDonald, have been privileged over the last decade to engage as curators and artists in highlighting art-focused approaches to representing ethnographic knowledge and power. This paper draws inspiration from work, both inside and outside art practices, that critically engages with the materialities of new technologies and their entanglements with our diverse practices as anthropologists (for example, Fig. 1., the work presented by Public Lab for Open Technology and Science in the 2011 Ethnographic Terminalia exhibition Field, Studio, Lab at Montréal's Eastern Bloc Centre for Interdisciplinary Art). But collectively, the authors of this essay are also troubled by the easy uptake of new tools and platforms in the service of what is being called the multimodal.

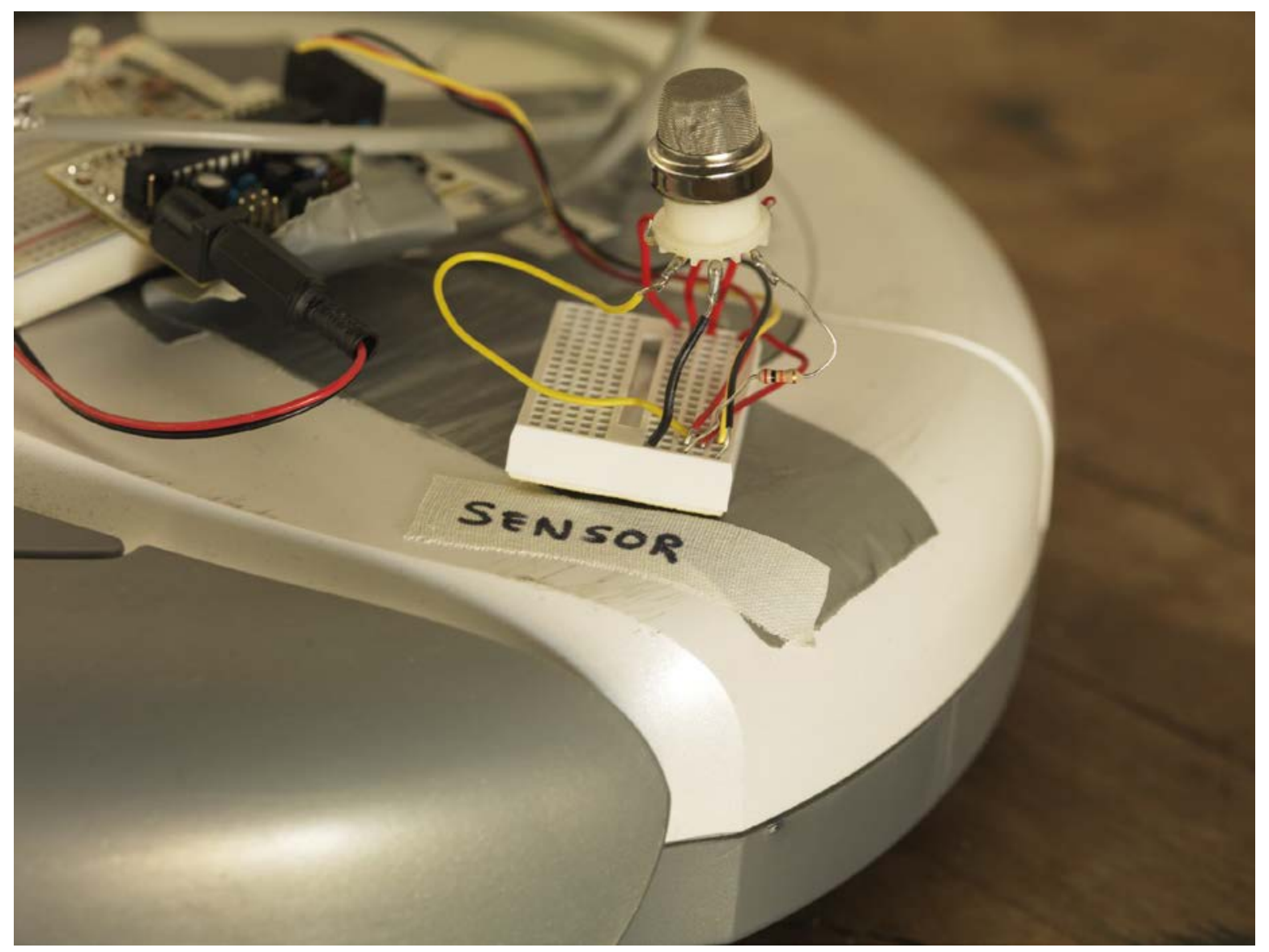

Figure 1. Making Sense: Lab as Gallery as Field. Public Lab for Open Science and Technology (Jae Ok Lee and Byeongwon $\mathrm{Ha}$ ). A DIY spectrometer and a Roomba hacked to be an indoor air pollutant mapper and generate realtime data about the gallery environment. Created for Ethnographic Terminalia 2011: Field Studio Lab, Montreal, Canada. Photograph by Rachel Topham for Ethnographic Terminalia.

That said, we do not believe we are somehow outside of bad habitus; rather, we fundamentally see ourselves as deeply implicated in the reproduction of technoscience and power hierarchies through our use of tools, networks, methods, and modes of dissemination. In addition to advocating for an anthropology of the multimodal alongside critical engagements with 
multimodal tools, we also envision bad habitus as a troubling feeling that is productive and necessary to recognize.

On the occasion of the 2018 meetings of the American Anthropological Association in San Jose, the heart of Silicon Valley, the authors of this article presented a round table called Bad Habitus: Anthropology in the Age of the Multimodal. We each provided examples from our research to open up entry points into thinking about anthropological histories, technological contexts, and multimodal potentials. Patricia Alvarez discussed the material topographies of "naturallysourced" dyes that destroy ecologies to consider the problem of creating film and collaborating with interlocutors in contexts when film or interactive documentary web-based projects aren't likely to be viewed or easily accessed by the interlocutors-collaborators. Deborah Thomas described the collaborative multimedia work and installation Bearing Witness: Four Days in West Kingston (Thomas, Bell, and Wedderburn, 2017) and pointed to counter-uses of surveillance (and practices of filming police) even as they come up against the legal limits of justice under racial capitalism. Trudi Lynn Smith and Kate Hennessy's presentation on the destabilization and anarchival materiality of colour motion picture film raised the question of the material resistances of pink ruin at play in the archives of salvage anthropology. Coleman Nye introduced a collaborative graphic adaptation of anthropological research (Hamdy and Nye 2017) and evaluated possibilities for practices of citation and collaboration through graphic forms while thinking through documentation of the intimate experience of illness alongside the complex social, economic, and environmental landscapes that shape health. Shalini Shankar's reflection on the challenges of representation in anthropology questioned the role the multimodal might play to "decolonize anthropology" particularly through the uptake of social media and the political projects anthropologists are engaging in: \#MeToo and \#HAUtalk, minoritized community conversations, and reordering the public sphere without an invitation. Jenny Chio quoted Dean MacCannell, who in another AAA panel exclaimed "Stop admiring your tools," and drew on artist Hito Steryl's In Defense of the Poor Image (2009) to call attention to the excess, the waste, and the detritus of the multimodal as a means of recognizing the chains of obligation and responsibility in which all of our work is enmeshed. Stephanie Takaragawa brought attention to our complicity in our bad habitus: How is our bad habitus enmeshed in issues of power and hierarchy that we are complicit in reproducing in within the academy, via hiring, lecturing, tenure and citational practices?

Discussion of these projects helped us shape an articulation of bad habitus and reorient attention towards what we think of as an anthropology of the multimodal. We ask, what is taken for granted in current mobilizations of the multimodal in anthropology? For the purposes of structuring our initial thoughts here, we have divided the discussion into two parts: 1) Multimodal inheritances, which begins to situate multimodal practices within recent critiques of the discipline itself, and, 2) Multimodal anthropology in the context of global capitalism and rapidly developing technologies like Artificial Intelligence that our work is increasingly making use of, whether we realize it or not. We finish up with an invitation to get comfortable with feeling bad about our bad habitus. Building on initial provocations around the multimodal, and following the work of many brilliant scholars who are provoking critical discussion around science and technology in society and culture (certainly there are so many more than we cite here), we aim to connect this kind of 
deep engagement with technology, representation, and its real-world implications, to future discussions and articulations of what is for now being called the multimodal in anthropology.

\section{Part 1: Multimodal Inheritances}

How do current articulations of multimodal anthropology and the tools and methods we take up within it have deep roots in anthropology as a discipline? How is multimodal anthropology also fundamentally entangled in capitalism and technoscience? As anthropology proliferates with new tools and ways of using them, we join others in highlighting how racism, misogyny, colonialism, ableism, and extractivism remain central concerns in considering the direction anthropology is taking and what it will become. As Cedric Robinson argued, constructions of race and capitalism evolved together producing a modern world system of racial division and expropriation: "'racial capitalism' (is) dependent on slavery, violence, imperialism, and genocide" (Kelley 2017). Michelle M. Wright reminds us that constructs of racialized identity are "produced through history, culture and ancestry, which are predicated on a notion of time and space that is linear and driven by progress," that we must be mindful of to understand who and how individuals perceive and perform themselves (Wright 2015:14). As our technologies and our methods co-produce and reinforce one another, what can we be doing to better identify and deconstruct how the multimodal has been produced and what it has inherited?

In the opening of her influential essay, The Phenomenology of Whiteness, Sarah Ahmed asks, "What does making the invisible marks of privilege more visible actually do?" (Ahmed 2007: 149), she considers how whiteness - "a social and bodily orientation"—is imbricated within institutional habits, inheritances, techniques, proximities. On the blog Feminist Killjoys, and in the book Living A Feminist Life (2017), Ahmed writes about doing diversity work and "the hardening of histories into barriers in the present" (2017:154). Ahmed asks, "how is 'white men' a building" (2017:154)? Ahmed provides abundant illustrations from everyday life in the university such as academic citations in the Ivory Tower that continue to be built on the alleged legitimacy of the able-bodied white man, reproducing White habitus (Bonilla-Silva et al. 2006), heteronormativity (Gill 2017), ableism (Nakamura 2013b) among others in academia.

When audit culture (Strathern 2000) requires that we have the requisite citations for tenure, and the editorial boards of peer reviewed journals are determined by like-minded scholars, are we only able to reproduce the status quo? Multimodal tools and what appears to be a growing acceptance within anthropology and interdisciplinary departmental tenure committees of nontextual work (for example ethnographic films and interactive media, exhibitions, curatorial activities, and research-creation) have, we suggest, created a sense that multimodal tools may be one way to subvert dominant narratives of success based on a single-authored monograph or article. However, an acknowledgement of our bad habitus necessarily means assuming a critical position in relation to the use of multimodal tools, which also reproduces the dynamics and power hierarchies entrenched in anthropology. The recent exposure (Yates-Doerr 2018; Weiss 2018) of violent practices in the production of the online open-access journal Hau was a disturbing reminder of these inheritances and also pointed to the ways in which our multimodal tools, like online journal platforms and digital editorial workflows can inherit and reproduce unequal relations of power in academia (see Cultural Anthropology Hot Spots Series edited by 
West 2018). This was addressed productively in the standing-room-only Late-Breaking American Anthropological Association Roundtable Destabilizing Power and Asserting Praxis in Post-HAU Anthropology at the 2018 Meetings in San Jose.

Zoe Todd, who was a discussant in that session, has influenced us very much in our thinking here about the way the multimodal in anthropology is being taken up. In her blog post The We and Them of Anthropology (Anthrodendum 2015), she interrogates the limits of the 'we' in anthropology. Building on Sarah Ahmed, Todd asks, "what would anthropological discourses look like if the halls of the academy physically reflected the actual societies we belong to?" Todd calls for anthropology to join the conversation about what matters to the non-dominant voices and bodies of the discipline, to:

embrace the vulnerability, and potential, that comes with radically dismantling the ongoing patriarchy and white supremacy of contemporary Euro-Western academia. Anthropology re-imagined is anthropology unbound from its current Euro-Western institutions and logics.

In a more recent blog post about racism, white supremacy and colonialism in anthropology, Todd (2018) draws on the work of Audra Simpson (2014) to ask how she can "refuse [anthropology's] underlying white supremacist tendencies"? In reminding anthropologists that decolonization is an ongoing process, she asks, "So what does it look like for us to engage more epistemic diversity, to be more generous and generative with the work that we do, with the bodies (human and figurative) that we carry within our disciplinary walls? I am not sure".

We aren't sure either, but we are grateful to Zoe Todd and others (Shankar 2018) for reminding us that the feeling of uncertainty is an important impulse in engaging and refusing oppressive dynamics in anthropology, including within what is being called the multimodal. Similarly we are motivated by the important work of Maya J Berry, Claudia Chávez Argüelles, Shayna Cordis, Sarah Ihmoud, and Elizabeth Velásquez Estrada, who argue for a fugitive anthropology (2018). In addressing contradictions of politically engaged research in fieldwork, Maya J. Berry and coauthors call for a feminist praxis of "fugitive anthropology, a rethinking of the contours of the political in co-creating spaces of liberation and transformation" (2017:538). Highlighting the ongoing power asymmetricalities of the academy, the authors write that they build a "framework for alternative pathways towards a politically engaged research we term fugitive anthropology" (2017, 540), that brings embodiment and embodied experiences to the practice of activist anthropology. This significant work, grounded in "black feminist analysis and praxis and inspired by indigenous decolonial thinking" (2017:559) locates "a fugitive anthropology...(that) cannot be tethered to preordained courses or predictable paths; it moves forward with an understanding that the path to reach spaces unknown is necessarily unpredictable" (2017:560).

In that line of thinking, we see bad habitus as including the unsettled feelings that we get in our guts - the instinctive and visceral reminders of our bodies (including the reminder to be aware of differences between bodies). As anthropologists we have long been concerned with the study of people, and have used technologies of the time to document human expression and activity in 
text, sound, and image. Anthropologists have and continue to demonstrate faith in these technologies to preserve a record of human activity - a salvage paradigm that today is undermined by deteriorating film stock and obsolete file formats (see Smith and Hennessy forthcoming). Museum anthropologists have long pointed out the contradictions between the documentation and the transmission of cultural heritage, in which documentation becomes frozen once removed from dynamic lived experience (Krmpotich 2004; Krmpotich et. al. 2003; Kurin 2004, 2007; Kirshenblatt-Gimblett 2004). We wonder if the momentum of sensory anthropology (Nakamura 2013a, Pink 2009, 2012; Howes 2003) and its activation with multimodal tools replicates this belief in the potential of new technologies to faithfully document and represent human experience for the future? Are multimodal methods in sensory anthropology claiming to narrow the gap between documentation and lived experience? How are disciplinary inheritances and orientations enmeshed in the enchantment of the new being reproduced and amplified with new tools? We suggest uncritical multimodal approaches may interject yet another layer of impediment to representing the experience of the gendered, aged, raced, abled or otherwise, body of the individual. Even more, Jeff Chang (2016) calls our current moment potentially one of "resegregation" as technologies of surveillance (Yesil 2006) are deployed for our safety, but disproportionately used against religious minorities and people of color (Browne 2015; Breland 2017; Jackson 2008). The bad feelings that recognition of such dynamics produces compels anthropologists to recognize that such devices are deployed for the convenience of some through the labor and loss of others.

Part 2: Multimodal's position in the context of global capitalism

The aspiration for a multimodal anthropology rests on the ongoing habits of technoscience. Through the lens of bad habitus, we are asking: who is able to take the orientations of technology for granted? How do they reinforce dichotomies between 'the human' and 'the machine'? As eurocentric epistemologies struggle with dichotomies between human and nonhuman, Jason Edward Lewis, Noelani Arista, Archer Pechawis, and Suzanne Kite consider the importance of Indigenous epistemologies in thinking about the non-human in discussions of Artificial Intelligence. In Making Kin with the Machines (2018), the authors work to "figure out how to treat these new non-human kin respectfully and reciprocally-and not as mere tools, or worse, slaves to their creators" and remind their readers of the importance of recognizing the porous boundaries between what is understood as 'the human' and 'the machine'. These communities are fundamentally entangled and complex arrays. The authors write:

The world created through Western epistemology does not account for all members of the community and has not made it a possible for all members of the community to survive let alone flourish. The Western view of both the human and non-human as exploitable resources is the result of what the cultural philosopher Jim Cheney calls an "epistemology of control" and is indelibly tied to colonization, capitalism, and slavery. Dakota philosopher Vine Deloria, Jr. writes about the enslavement of the non-human "as if it were a machine" (2018:Para 38).

Many technologies being used in anthropology today are fundamentally implicated in the oppression of people through unequal labor, distribution of resources, and alienation from land, 
disproportionately affecting marginalized groups in developing worlds, as well as minority groups in industrialized spaces. We are inspired by recent ethnographic work that aims to disentangle complex sociotechnical arrays and their human effects. For example, Mary Gray's work on the labour infrastructures of Amazon's Mechanical Turk (2016) and forthcoming book represents deep ethnographic study of the implications of taskified labour outsourcing and its undermining of hundreds of years of labour rights activism. In another example, a special issue of Cultural Anthropology $(33.3,2018)$ edited by lan Lowrie foregrounds algorithms and automation as shaping the socio-technical assemblages that increasingly organize human experience in a way that transcends future possibilities for human control and comprehension. And, in a similar impulse to unpack the invisible in the everyday, Josh Bell, Briel Kobak, Joel Kuipers, and Amanda Kemble's special issue of Anthropological Quarterly (91(2) Spring 2018) on the materiality of cell phones brings ethnographic methodologies and ideas of object biographies together to explore the deep social and environmental impact of mobile phone use and the material supply chains that enable its proliferation.

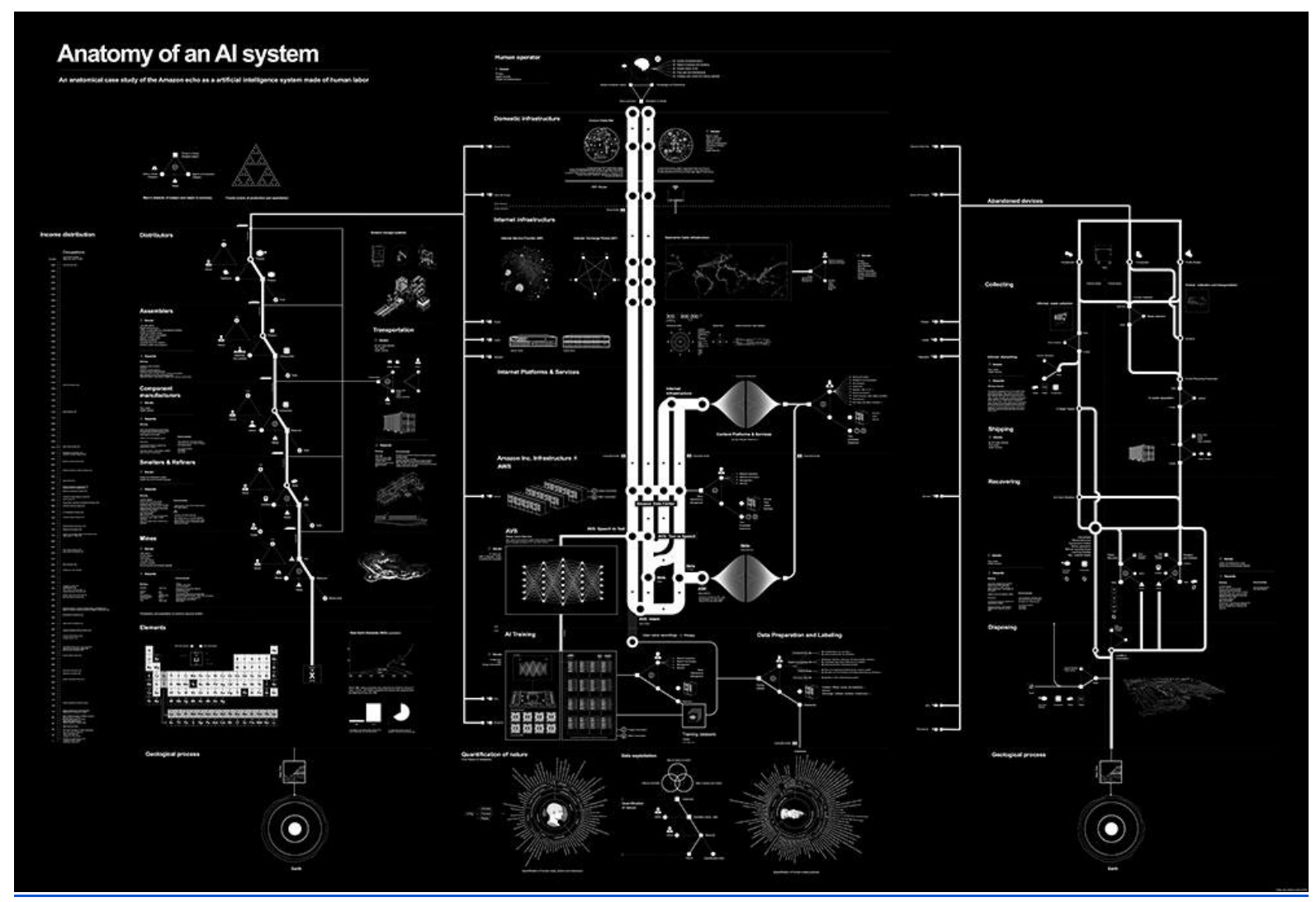

Figure 2. Kate Crawford and Vladan Joler, Anatomy of an AI System (2018). https://anatomyof.ai/

A provocative example of using a material object as a starting point for critically decoding its mind-boggling human and environmental effects-from deep geological time to the cloud and back to the landfill-is Kate Crawford and Vladan Joler's Anatomy of an AI System (2018). They take a typical interaction with the Amazon Echo-a mother holding a child asking Al-assistant Alexa to turn on the lights - and explode it into a graphic-narrative of racialized capitalism in which "a vast matrix of capacities is invoked: interlaced chains of resource extraction, human 
labor and algorithmic processing across networks of mining, logistics, distribution, prediction and optimization (Crawford and Voler, 2018 para. 1). The authors point out that the small moments of convenience that new technologies provide (turning on a light, calling up a song) require a scale of resource use that far exceeds what it would take a human to do the same work; and, while making sense of these costs is near impossible, "it is increasingly important that we grasp the scale and scope if we are to understand and govern the technical infrastructures that thread through our lives" (Crawford and Voler, 2018 para. 2).

Can we begin to practice an anthropology of the multimodal that is grounded in questioning technoscientific praxis? The current framework proposed for multimodal anthropologies seems to avoid critiques of technological determinism by keeping a space open for new technologies in the present and future. However these technologies and media forms, often appear, inveigh themselves, and disappear before we have a chance to fully understand what has happened. Other forms undergo technological and formal shifts, which sometimes we make meaningful, and sometimes we fail to capture. What is implicated in the move from the calotype to photographs to film to video to digital medias? From single images to comics to graphic novels? From salon style installations to immersive multimedia environments? We agree with Collins, Durington and Gill that the multimodal is a "constant space for new technologies and modes of dissemination to be recognized and welcomed by necessity" but should be approached with caution (Collins, Durington and Gill 2017). Crawford and Voler recall Jean-Francois Lyotard's phrase "'affinity to infinity", a phrase used to "describe how contemporary art, techno-science and capitalism share the same aspiration to push boundaries towards a potentially infinite horizon" (Crawford and Joler 2018, para. 19).

Grappling with the complexity, scale and scope of technical infrastructures raises further questions about the limits for multimodal anthropologies if they are harnessed to a future controlled by capitalist corporations. What happens when the intention of a new technology is to capture energy, dollars and resources? How might we (or do we) nurture and maintain media worlds that exceed these capitalist technoscientific futures? How do we best resist giving algorithms a monopoly on the multimodal experience? This might be the thought experiment: What of multimodal anthropology when the power goes out?

Elizabeth Chin (2016) reminds us that new technologies are commodities, and therefore work within the system of capital and extractive capitalist logics. This includes the variegated ways that commodities work, how commodities and consumption are taken up within power, within the middle class, within the academy, and within capitalism's relationship with race. Who benefits from an "affinity to infinity"? Who does not? Perhaps, rather than a welcoming act, in some cases an act of refusal may be necessary (see Ahmed 2018, Simpson, 2007, Todd 2018). If we believe in the promise of addressing inequity through the development and application of new technologies, we run the risk of naturalizing dynamics of oppression. This act reifies tropes of progress, rather than admitting that inequity is a state we are already complicit in constructing. Furthermore, we may unintentionally ignore how the multimodal is instrumental in furthering this divide by focusing on outcomes of technological change, rather than the input of technological labor and extraction. 
As Crawford and Joler caution,

Digital labor - the work of building and maintaining the stack of digital systems - is far from ephemeral or virtual, but is deeply embodied in different activities. The scope is overwhelming: from indentured labor in mines for extracting the minerals that form the physical basis of information technologies; to the work of strictly controlled and sometimes dangerous hardware manufacturing and assembly processes in Chinese factories; to exploited outsourced cognitive workers in developing countries labelling Al training data sets; to the informal physical workers cleaning up toxic waste dumps. These processes create new accumulations of wealth and power, which are concentrated in a very thin social layer (Crawford and Voler, 2018 para. 9)

So, we are wondering, if we as anthropologists fundamentally do not understand (or even care about) the technologies we use in the service of multimodal anthropologies, how can we begin to critically engage with our practices? If we claim to be grounded in collaboration with communities as partners in research, why are more of us not rethinking the technologies we use and their wide-ranging effects? Is the defense of the multimodal ultimately about having new forms of research using novel technologies and industrial funding accepted within the academy? And if so, is this being done at the expense of those whose data and representations are being mobilized through digital platforms and corporate servers, and perhaps the planet itself? 


\section{Bad Habitus and the potential of disorientation}

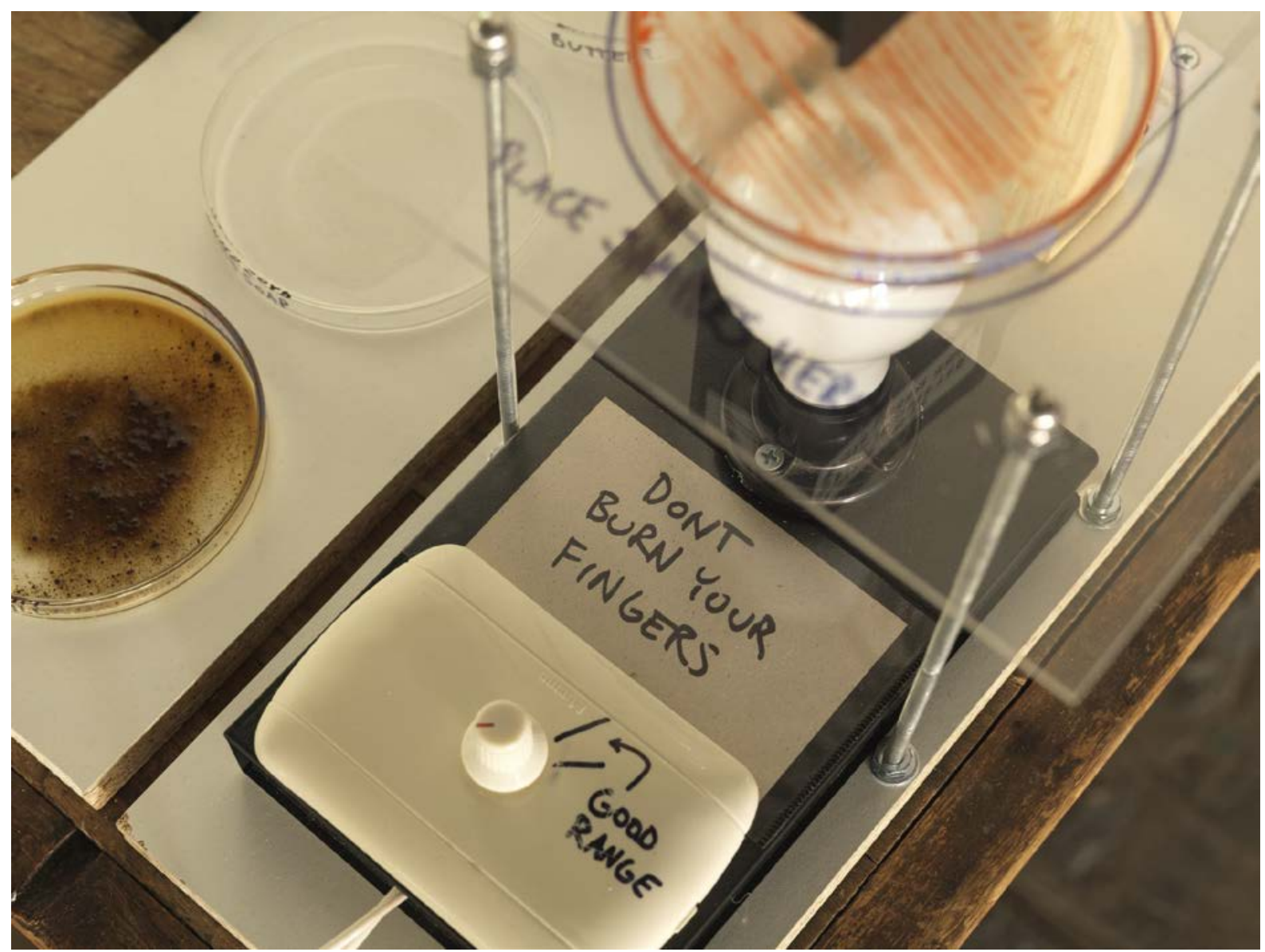

Figure 3. Making Sense: Lab as Gallery as Field. Public Lab for Open Science and Technology (PLOTS) (Jae Ok Lee and Byeongwon Ha). Created for Ethnographic Terminalia 2011: Field Studio Lab, Montreal, Canada. Photograph by Rachel Topham for Ethnographic Terminalia.

As we began to write this essay, we were particularly inspired by the ongoing work of Public Laboratory for Open Technology and Science (PLOTS) (Figure 1, Figure 3). We looked back at the work they contributed to the 2011 Ethnographic Terminalia exhibition in Montreal. In their work Making Sense: Lab as Gallery as Field, the artists take things apart and reconfigure them to actively reimagine and enact human relationships to science. They address and act on environmental injustices via DIY, open source techniques and trainings. At their core, PLOTS demonstrates that generating knowledge is powerful and should be democratic and available, not just in the hands of scientific experts. The artists remind us that when we don't understand technology or how it is being used, we should open the black box, take it apart, and figure out how the wires connect. Inspired by these actions, we call for an anthropology of the multimodal, premised on what we believe should be an ongoing obligation to try to make sense of the technologies and inheritances upon which multimodal practices depend. 
As Sarah Pink pointed out in 2011, multimodal approaches to ethnography appear to default to a classical ethnographic approach. As a challenge, she suggests: "Would it not be more informative and exciting to engage with new conceptualizations of ethnography, ethnographic knowing and empathetic research practices" (274)? We argue in this article that these new conceptualizations in anthropology require an acknowledgement of the multimodal's disciplinary inheritances as well as its embeddedness in global capitalism and technoscience. This is an acknowledgement grounded in recognition of the active and unfinished process of ongoing obligations, one we underscore here by employing Sara Ahmed's firm assertion that "It takes conscious willed and willful effort not to reproduce an inheritance" (2014:np).

Therefore we propose an anthropology of the multimodal as one way to address bad habitus. An anthropology of the multimodal finds grounding in Donna Haraway's ethic of "learning to stay with the trouble of living and dying in response-ability on a damaged earth" (2016:2). It is also about making "good trouble," as veteran Civil Rights leader Congressman John Lewis (DGeorgia) has repeatedly urged us to do. As anthropology of the multimodal stays with the trouble, it is an undertaking both disturbing and disorienting. Framing the importance of disorientation, Ahmed writes

...it is by showing how we are stuck, by attending to what is habitual and routine in 'the what' of the world, that we can keep open the possibility of habit changes, without using that possibility to displace our attention to the present, and without simply wishing for new tricks (2007:165).

Bad habitus is a critical approach that provides possibilities of recognizing the taken-for-granted positions of white bodies; privileged bodies; able bodies. It requires a suspicion of new tricks. It is also a feeling that is felt when confronting taken-for-granted positions. It is the conscience within us that allows us to work towards recognizing the ways in which we are each complicit in the generation of a bad habitus. As anthropologists, can we embrace this disorientation as generative? After all, isn't disorientation our preferred space? Disorienting the multimodal in anthropology, therefore, is a call to recognize and change our habits, reconceive the architectures in which we live, and rethink the technologies with which we work.

\section{References}

Ahmed, Sara. 2007. A Phenomenology of Whiteness. Feminist Theory 8(2): 148-168.

Ahmed, Sara. 2014. "White Men." Feminist Killjoys blog. November 4, 2014. Accessed November 12, 2018. https://feministkilljoys.com/2014/11/04/white-men/

Bauchspies, W.K., J. Croissant and S. Restivo. 2006. Science, Technology, and Society: A Sociological Approach. Hoboken, NJ: Blackwell Publishing. 
Bell, Joshua A., Briel Kobak, Joel Kuipers, and Amanda Kemble. 2018. "Unseen Connections: The Materiality of Cell Phones." Anthropological Quarterly 91(2): 465-484.

Berry, Maya J., Claudia Chávez Argüelles, Shanya Cordis, Sarah Ihmoud and Elizabeth Velásquez Estrada. 2017. "Toward a Fugitive Anthropology: Gender, Race, and Violence in the Field." Cultural Anthropology 32(4): 537-565.

Bonilla-Silva, Eduardo, Carla Goar and David G. Embrick. 2006. "When Whites Flocks Together: The Social Psychology of White Habitus." Critical Sociology 32(2-3): 229-253.

Bourdieu, Pierre. 1988. Distinction: A Social Critique on the Judgement of Taste. Chicago:University of Chicago.

Browne, Simone. 2015. Dark Matters: On the Surveillance of Blackness. Durham: Duke University Press.

Chang, Jeff. 2016. We Gon' Be Alright: Notes on Race and Resegregation. New York: Picador.

Chen, Nancy N. and Trinh T. Minh-Ha. 1994. "Speaking Nearby," in Visualizing Theory: Selected Essays From V.A.R 1990-1994, edited by Lucien Taylor. New York: Routledge. 43351.

Chin, Elizabeth. 2016. My Life With Things: The Consumer Diaries. Durham, NC: Duke University Press.

Chin, Elizabeth. 2017. "On Multimodal Anthropologies from the Space of Design: Toward Participant Making. Multimodal Anthropology Section." American Anthropologist 119(3): 541543.

Collins, Samuel, Matthew Durington and Harjant Gill. 2017. "Multimodality: An Invitation." American Anthropologist 119(1): 142-146.

Condliff, Jamie. 2018. "Foxconn Is Under Scrutiny for Worker Conditions. It's Not the First Time." New York Times Website. June 11, 2018. Accessed December 6, 2018. https://www.nytimes.com/2018/06/11/business/dealbook/foxconn-worker-conditions.html.

Crawford, Kate and Vladan Joler. 2018. Anatomy of an Al System website. Accessed September 20, 2018. https://anatomyof.ai/.

Gill, Harjant S. 2016. Film as a Powerful Feminist Medium. In Feminist Ethnography. Thinking Through Methologies, Challenges and Possibilities. Davis, Dána-Ain and Christa Craven

Gill, Harjant S. 2017. Censorship and Ethnographic Film: Confronting State Bureaucracies, Cultural Regulation, and Institutionalized Homophobia in India. In Visual Anthropology Review. Vol. 33, Issue 1, pp. 62-73. 
Gray, Mary. 2016. "Your Job is About to Get Taskified." Los Angeles Times Website. Jan 8, 2016. Accessed September 20, 2018. http://www.latimes.com/opinion/op-ed/la-oe-0110-digitalturk-work-20160110-story.html.

Hamdy, Sherine, and Coleman Nye. 2017. Lissa: A Story about Medical Promise, Friendship, and Revolution. Toronto: University of Toronto Press.

Haraway, Donna. 2016. Staying with the Trouble. Making Kin in the Chthulucene. Durham and London: Duke.

Harvey, David. 2014. Seventeen Contradictions and the End of Capitalism. New York: Oxford University Press.

Jackson, Jason Baird. 2018. "Community-Based Open Access, Fast and Slow \#hautalk." Posted June 20, 2018. http://allegralaboratory.net/community-based-open-access-fast-andslow-hautalk/.

Jackson, John. 2008. Racial Paranoia: The Unintended Consequences of Political Correctness. Basic Civitas.

Kelley, Robin. 2017. "Introduction." In Race Capitalism Justice. Boston Review. January 12, 2017. Accessed October 31, 2018. http://bostonreview.net/race/robin-d-g-kelley-what-didcedric-robinson-mean-racial-capitalism.

Kelly, Annie. 2016. "Children as young as seven mining cobalt for use in smartphones, says Amnesty." The Guardian Website. January 18, 2016. Accessed September 25, 2018.

https://www.theguardian.com/global-development/2016/jan/19/children-as-young-as-sevenmining-cobalt-for-use-in-smartphones-says-amnesty.

Kirshenblatt-Gimblett, Barbara. 2004. Intangible Cultural Heritage as Metacultural Production. Museum International 56 (1-2).

Krmpotich, Cara. 2014. The Force Of Family: Repatriation, Kinship and Memory on Haida Gwaii. Toronto: University of Toronto Press.

Krmpotich, Cara, Laura Peers, Members of the Haida Repatriation Committee, Staff of the Pitt Rivers Museum and Staff of the British Museum. 2013. This Is Our Life: Haida Material Heritage and Changing Museum Practice. Vancouver: University of British Columbia Press.

Kurin, Richard. 2003. Tangible Process: A response to "Safeguarding the Intangible," a Cultural Comment essay by Michael F. Brown. http://www.culturalcommons.org/kurin.

2007. Safeguarding Intangible Cultural Heritage: Key Factors in Implementing the 2003 Convention. International Journal of Intangible Heritage 2: 10-20. 
Lewis, Jason Edward, Noelani Arista, Archer Pechawis, and Suzanne Kite Making Kin with the Machines. 2018. Journal of Design and Science (JoDS) (np) Online. MIT Press.

Latour, Bruno. 1987. Science in action. Milton Keynes: Open University Press.

Lowrie, Ian. 2018 "Algorithms and Automation: An Introduction." Cultural Anthropology 33, no. 3: 349-359. https://doi.org/10.14506/ca33.3.01.

Moore, Henrietta L. 1994. "Trinh T. Minh-Ha Observed: Anthropology and Others," in Visualizing Theory: Selected Essays From V.A.R 1990-1994, edited by Lucien Taylor. New York:

Routledge, 115-25.

Nakamura, Karen. 2013a "Making Sense of Sensory Ethnography: The Sensual and the Multisensory," in American Anthropologist 115(1):132-144.

Nakamura, Karen. 2013b. A Disability of the Soul: An Ethnography of Schizophrenia and Mental IIIness in Contemporary Japan. Ithaca, NY: Cornell University Press.

OED. 2018. Multimodal. OED online, entry from the Third Edition March, 2003.

Deborah A. Thomas, Deanne M. Bell, Junior "Gabu" Wedderburn, curators. 2017. Bearing Witness: Four Days in West Kingston. Penn Museum.

https://penn.museum/exhibitions/galleries-and-exhibitions/bearing-witness.

Pink, Sarah. 2011. "Multimodality, Multisensorality and Ethnographic Knowing: Social Semiotics and the Phenomenology of Perception." Qualitative Research 11 (3): 261-76.

Ruby, Jay. 1991. "Speaking For, Speaking About, Speaking With, or Speaking Alongside- An Anthropological and Documentary Dilemma," Visual Anthropology Review 7(2): 50-67.

Shankar, Arjun. 2018. What Do We Want Anthropology to Resemble? Anthropology News. Posted September 7th, 2018 at http://www.anthropology-news.org/index.php/2018/09/07/whatdo-we-want-anthropology-to-resemble/.

Steryl, Hito. 2009. "In Defense of the Poor Image." E-Flux. 10 (November). Accessed December 11, 2018. https://www.e-flux.com/journal/10/61362/in-defense-of-the-poor-image/.

Strathern, M. (ed.) 2000. Audit cultures: anthropological studies in accountability, ethics, and the academy. London: Routledge.

Thomas, Deborah A., Deanne M. Bell, Junior "Gabu" Wedderburn, curators. 2017. Bearing Witness: Four Days in West Kingston. Penn Museum. https://penn.museum/exhibitions/galleries-and-exhibitions/bearing-witness. 
Todd, Zoe. 2015. The We and Them of Anthropology. Savage Minds. Posted May 16th, 2015 at https://savageminds.org/2015/05/16/the-we-and-them-of-anthropology/.

Trihn, Minh-Ha. 1992. Framer Framed. New York: Routledge.

Vidal, John. 2017. 'Tsunami of data' could consume one fifth of global electricity by 2025. The Climate Change News. Published on 11/12/2017, 10:57am.

http://www.climatechangenews.com/2017/12/11/tsunami-data-consume-one-fifth-global-

electricity-2025/.

Weiss, Jules. 2018. Citation is a Gift: "Punking" Accounting in \#hautalk. Accessed December 5, 2018 at https://footnotesblog.com/2018/07/07/guest-post-citation-is-a-gift-punking-accountingin-hautalk/

West, Paige. 2018. "From Reciprocity to Relationality: Anthropological Possibilities." Cultural Anthropology Online, September 26. Accessed December 11, 2018.

https://culanth.org/fieldsights/1525-from-reciprocity-to-relationality-anthropological-possibilities.

Wright, Michelle M. 2015. Physics of Blackness: Beyond the Mlddle Passage Epistemology. Minneapolis and London: University of Minnesota Press.

Yesil, Bilge. 2006. "Watching Ourselves: Video Surveillance, Urban Space and SelfResponsibilization." Cultural Studies 20(4-5): 400-416. 